\title{
Towards a Framework to Create Shared Value Partnerships in the Community Evidence from Egypt
}

\author{
Wael Omran Aly ${ }^{1}$ \\ ${ }^{1}$ High Institute of Foreign Trade and Management Sciences, New Cairo Academy, Egypt \\ Correspondence: Wael Omran Aly, High Institute of Foreign Trade and Management Sciences, New Cairo \\ Academy, Egypt. E-mail: wael.omran@ymail.com
}

Received: January 31, 2019

Accepted: April 21, 2019 Online Published: April 29, 2020

doi:10.5539/par.v9n1p51

URL: http://dx.doi.org/10.5539/par.v9n1p51

\begin{abstract}
Government and non-government organizations (NGOs) basic reaction to the pace and scale of international changes has been a hesitancy to recognize adequately the need to modify themselves. Problems tend to be interdependent as well as bundled, needing thorough approaches as well as common participation. On the other hand, the private sector in developing countries providing on average 60 per cent of GDP, 80 per cent of capital flows and 90 per cent of jobs. As a result, a solid along with vital private sector is essential for help Developing countries move from associations depending on aid towards types depending on economic partnerships. Consequently, developing a collaboration dependent upon creating shared value (CSV) credo by using the private sector - rather than the conventional social responsibility approach- is a must to increase the impact involving aid investments while bringing in business growth. Hence, such paper aims to depict the suitable framework to create shared value policies and practices that enhance the competitiveness of private sector companies while simultaneously advancing the economic and social conditions in the communities in which they operate. Moreover, it tends to detect barriers impeding the realization of such framework; and the needed pillars to overcome such barriers in developing countries as Egypt.
\end{abstract}

Keywords: social responsibility, creating shared value, partnerships, Egyptian community

\section{Introduction}

Philanthropy and Corporate social Responsibility (CSR) are excellent way to help a country, but definitely not the way in which for having a great state - Creating Shared Value (CSV) is. Through CSV, firms can counteract the government's burden and build prosperity to any or all stakeholders. It's generally thought that corporations prosper at the expense of society and environment. This is not a completely unjust accusation. Several corporations neither take into account the city wellbeing or the environmental influence of these operations. Businesses have already been stuck for years into their greed over temporary benefits to indulge shareholders (Kramer, 2012).

Not enough rely upon business companies led governments to get intense actions, and impose rules and regulations that adversely influence competitiveness and productivity. This ultimately restricted the economy's development, causing the financial, social and environmental issues unsolved (Maha Farouk, 2014). But could governments, NGOs or philanthropists resolve these issues alone? Is there an exit of this ferocious round?

Government and NGOs cannot tackle these challenges alone. Harnessing the ability of organization to operate a vehicle prosperity and lower poverty hasn't been more required or more probable than it is exact now. Business corporations are active in shaping the brand new global United Nations Sustainable Development Goals, and as a result we are seeing the quick rise of sustainability as a worldwide priority for business. The aims, benefits and values between aid and business have reached a momentous junction (Commonwealth of Australia, 2015).

Hence, Creating Shared Value could function as light at the end of the tunnel. According to Michael Porter and Mark Kramer (2011), this notion is especially about creating economic value for businesses in a manner that similarly creates value for the society by dealing with its unmet needs. Business must perform hard to reconcile Corporations' accomplishment with social development and benefit. Shared Value is not social responsibility, philanthropy, or even sustainability. It is a new way to attain global financial increase even though providing 
intended for society's benefits. Hence, Government allows business enterprises to create shared value partnerships in the community; by supplying empowering rules, assets, and benefits in addition to organizing power.

Thereby, this paper tends - via analytical descriptive methodology- to find the answer for the following research question: "What is the suitable framework to create shared value partnerships in the community"? Therefore, the researcher aims firstly to shed light on creating shared value concept. Secondly, to identify the different partnerships forms in the community. Thirdly, to prescribe a framework to create shared value partnerships in the community. Finally, to detect the main barriers to adopt such proposed framework at the Egyptian community and to recommend some pillars to overcome effectively these barriers.

\section{Creating Shared Value Concept}

Governments have not dealt yet successfully with societies' biggest challenges; while that philanthropy didn't have the resources. The "magic" (Porter's word) with integrating money-making by using social beneficial is that often, like every successful action, the mechanisms of capitalism try to expand along and repeat the activity: "When we get [Shared Value] into the capitalist bucket... we can scale. We can sustain activity indefinitely. We can actually solve problems!" (Mark Kramer, 2013).

Creating Shared value is looked as regulations and techniques that enhance the competitiveness for firms whereas improving social and environmental circumstances inside territories where by companies operate. This is organization process aimed at firms establishing measurable monetary benefit by simply figuring out and dealing with social issues; that overlap with their business. To become qualified as shared value, there has to be the recognizable financial benefits of the organization in addition to measurable effect on any social or environmental concern (Michael Porter \& Mark Kramer, 2011).

Subsequently, shared value brings about brand-new options for businesses, civil community organizations, and also governments so that you can make use of the strength of market-based competition throughout dealing with sociable difficulties, and has produced fast from a universal notion to a sort of business working at its paramount The launch of the formal shared value concept came after the period of Global Financial Crisis when capitalism and your status of business were less than duress (Silvia Mattei, 2015). The concept appreciates the benefits of business, using its capital, market admittance, and also eases of innovation, and its capability of obtaining special effect on societal problems. It looks at the social dimension of a business, the link among the people, resources, products, services, investments as well as systems to external stakeholder parties for example communities, supply chains, consumers as well as regulators (Michael Porter \& Mark Kramer, 2011).

It is usually apparent that once we discuss about Shared Value; it seriously isn't in relation to spreading pre-existing value (which will be, effectively, what philanthropy is) but about creating new value for both shareholders and the community, together (Mark Kramer, 2013). As well, it is actually not corporate social responsibility (CSR) where companies concentrate primarily on developing their own standing by way of things to do who have minimal link with their own company operations. (Michael Porter \& Mark Kramer, 2006). In addition, this isn't Shared Value when it is done simply by an institution that isn't pushed simply by the profit necessity, along where the "magic" of capitalist growth is usually absent. Therefore the public organization, possibly when it is 'doing well' isn't creating Shared Value because profit just isn't there as a carter of progress (Mark Pfitzer et al., 2013).

Changing CSR to CSV is done by pinpointing the interdependence between the company's activities and the community. Considering a new company's competitive advantage plus critical value is essential to assure that this shared value is going to instantly feed in the social problems together with the company's earning (Michael Porter \& Mark Kramer, 2011). Productive firms need healthy communities in order to foster accessible global financial development. They want knowledgeable, vigorous as well as endowed employees. Otherwise, a healthy contemporary society could use a prosperous business to provide careers, wealth, development and better living standards (Michael E. Porter, 2012). Firms may possibly neither be absolutely in charge for all of the world's challenges nor must they get the particular recourses to unravel them. Still, every single business can certainly recognize areas where shared value can be made to cultivate a community and in the end the whole country (Mark Pfitzer et al., 2013).

Eventually, businesses require achieving whole understating of their different stakeholders to greater meet their needs, achieving the initial step in CSV. The second step is to transform stakeholders' needs, demands and motives into a shared value; that will eventually bring viable profits to the business (Silvia Mattei, 2015). But how is shared value created? And how could this apply to the developing economy -as the Egyptian one- to help develop the country? There are three well recognized ways to create shared value, linking businesses to the community (Michael Porter \& Mark Kramer, 2011): 


\subsection{Reconceiving Products and Markets}

In almost any presented current market, you'll find considerably more social needs than these by now found as well as far better day-to-day lives, far better housing, as well as considerably better financial services. Useful scrutiny within communities for the people needs can still start completely new unleashed chances to serve society; by Developing completely new products and services for established or perhaps new markets depending on collaboration with consumers as well as community stakeholders to recognize social needs. A terrific model is Life insurance company AIAAustralia'sStrength program locates precautionary health problems simply by encouraging clients to reside healthy life through compensations programs and lesser payments. As a result, creating a much healthier client base and decreasing dues costs for that company. Another critical model which will probably be worth duplicating in developing countries- as Egypt- is Intel's Training Alteration strategy. This particular step is focused on advancing the performance involving each professors and also students. Looking into just what is very wanted to further improve a class perform, Intel could provide technology alternatives to increase students result in class; improving product sales involving classroom technologies across the way (Maha farouk, 2014). Mounting this particular model through a genuine relationship between private software and information technology companies with NGOs and the public sector could create shared value to the community while supporting these organizations expand economically. This might be reached simply by developing the need in educational institutes that is going to commute product sales to Intel Company, developing the latest technology dedicated to its brand name (Brand Connection). Intel company vision that soon all those technology would be an essential need as opposed to a luxury in any schools; the substance in their business value.

\subsection{Redefining Productivity in the Value Chain}

The primary new driver with this technique of creating shared value is the company's value chain. There are many opportunities readily available for greater managing a corporation's value chain to lower cuts, maximize benefits and make shared value. Assets are invariably several activates for CSV through the value chain; by working along with suppliers as well as internal/external stakeholders to further improve processes, quality, sustainability, productivity, social outcomes as well as competitive advantage. Among the good example is the fact that NAB (National Australia Bank) produced NAB Assist, encouraging and training many collection agencies staff to spot, deal with, and proactively assist shoppers inside monetary difficulty, therefore significantly decreasing loan defaults and costs regarding your budget, and increasing the volume of customers who seek an item of tips prior a collections affair. Yet another good model corporations might adopt in Egypt is investigation joint ventures with Egypt universities. Firms could finance universities to explore and grow revolutionary strategies to minimize the use of electricity, water and another tight resource (Maha farouk, 2014). This idea would make provided cost to the community trim down the company's substantial expenses on this portion of the value chain. This may be move up to as much problems and companies. Through the use of research and technology to unravel problems; an organization would develop a new value, or perhaps create a brand-new revolutionary product that a substantial number of consumers need.

\subsection{Building Supportive Industry Clusters}

The following technique is capable of doing magic on the nation's advancement plus countered a terrific problem on the government's shoulder. Enabling cluster advancement could apply to as numerous clusters as possible imagine; simply by facilitating the actual clustering and sustainable development of industry within regional conditions that the company operates. Additionally, this can certainly include setting up the actual capabilities involving suppliers as well as civil corporations, or managing to renovate the actual regulatory design to allow commerce although bettering conditions. The visible illustration will be Bendigo and Adelaide Bank which made its community Standard bank model, aiding self-selecting communities to manage their unique twigs since franchise companies, profiting the actual bank's financial providers, infrastructure as well as knowledge, although reinvesting parts of the actual income directly into the community to drive lasting growth (Sam Moore, 2016). Yet another illustration includes the intact tourism and hotel management cluster. Due to the proper consideration, producing this market might take the country into an additional league. As in Egypt, Tourism represents exceptional competitive advantage which often can drive the economy. Global hotel groups can certainly create shared value by enabling tourism cluster growth. Financing training and development to offer sophisticated knowledgeable personnel would likely develop fantastic shared value. It would likewise trim the hotels' human resource expenditures in any recruiting, training in addition to development activities. This progress would likely gain higher quality to figure across the business, building a different common bench mark for top quality, and consequently developing specialized competitive advantages for the country (Maha farouk, 2014). The cluster development could be expanded to add all the touristic supporting capabilities just like hotels services, relevant shopping outlets in addition to transportation facilities. 
Therefore, Shared value is a brand new method changing the concentration of the corporation coming from "shareholder" to "stakeholders." It is truly bigger in scale; stakeholders encompass the many sorts of people that will be right afflicted by company procedures like shareholders, consumers, workforce, partners and society. Moreover, shared value acknowledges that the creation of both societal and economic value as a competitive advantage that may lead creativity and offer the long-term version and abundance to the corporation (Shared value leadership summit, 2015). Shared value can end up being created through various roles in addition to business functions, from supply chain management and research and development to community commitment. Thus, it is an integrated strategy, rooted in the entire business planning, and needs reassessment of member of staff roles and teams.

\section{Partnerships' Forms in the Community}

Government and NGOs are facing restricted options along with issues inside scaling social solutions. Enterprises currently have resources along with capacity that overpass those of other stakeholders. Nevertheless, businesses cannot take action alone. NGOs ought to work with others along with business enterprises, having updating knowledge along and strong connections along with stakeholders. Government had to endow system, spur markets, and manage in manners that motivate shared value (Danielle Sponder Testa, 2011). Such as, the Kenyan government modified banking regulations, which braced the actual launch and also growth of the revolutionary mobile phone-based money transfer and loan service to low income people. While the right type of government regulation can certainly encourage businesses to engage in shared value, the wrong type acts counter it and additionally makes swaps between economic and social goals unavoidable (Shayta Roy, 2013).

Moreover, much can be said about building shared value internally, but equally important is the establishment of shared value externally. Uptake will require scale, and achieving scale is challenging without the combined efforts of many different actors working together (Eichler, Michael, 2004). Moreover, a great deal can be said with regards to building shared value internally, nonetheless equally important could be the place of shared value externally. Its adoption will necessitate broad extend, and having broad extend is usually demanding without having the bundled initiatives of numerous various parties collaborating mutually. As a result, the significance of cross-sector relationship that will arise as shared value is never one movement. It takes a great ecosystem regarding actors and partners that will at the same time modify the patterns of value creation throughout bigger firms, checking combined role of social affect and conventional business enterprise systems (John Mennel et al., 2013). Doing so will enable those engaged in shared value to make greater strides in achieving impact, while at the same time revolutionizing the ways in which we work together.

Subsequently, the concept of shared value must make up the foundation acquiring developing countries vision; that businesses can easily offer maintainable social influence in such countries as Egypt; though acquiring business returns. As a result, locating brand new and inventive tips on how to enhance collaboration in addition to partnering concerning government, the private sector and NGOs will often be important to recognizing that vision. Partnerships signify the particular epitome associated with leadership in addition to interrelationship inside municipal society. Not only a " purchase order", real partnerships are the roughest, enjoyable, and useful type of decision-making offered to all of us (John lavey, 2017). The challenges facing communities nowadays are numerous and complicated, in addition to really exist on an array of scales. But partnerships are becoming ever more the solution pertaining to conditions that require numerous stakeholders or need the efforts of numerous brains to collaborate and create shared values. Agencies pursue partnerships to increase value via bundled efforts. Though companies can have different structures in addition to techniques, they could collaborate together toward common aims and achieve collective outcomes (Commonwealth of Australia, 2015).

So, a partnership is your give-and-take association that will enhance agencies' capability of long-term cooperation and collaboration. To achieve the possible advantages of partnership, agencies will have to develop, preserve, and evaluate them in a considerable technique (Regina Brandstetter et al., 2006). A partnership can be thought of as a collaborative relationship between organizations (World bank, 1998). The aim of this relationship is usually to work toward shared goals; by having a division of jobs that everyone concurs on. Partnerships are complicated means for providing realistic resolutions to societal and community issues (Smith, Steven R., 1997). The researches to partnerships methods of operation indicate that organizations tackle the complexness by fostering a long-term, lean and adaptive approach. Throughout the path of their partnerships, organizations often develop. They acquire the criteria of effective management, create total capacity, and reap priceless experiences. For that reason, a partnership can be an adequate learning tool; that demonstrates to every partner the way to better performance necessary to realize various corporate goals (Timothy A.A. Stiles \& Trevor Davies, 2016).

There are lots of kinds of partnerships, for instance people among community-based nonprofits or even among 
nonprofits along with corporations. The factors in which partners have to ponder as well as structures these people identify will be different according to the types of agencies involved along with the types of interactions these people elect to include (Tranel, Level \& Kay Gasen, 2003). Even so, within every kind of partnerships, it's important to develop these advantages of all of the participating organizations. Nowadays, we have seen an elevated interest in partnerships that emphasis on community improvement. Agencies at the Federal and state levels, universities, corporations, and national nonprofits could all offer boosts to partnerships that have the ability to develop community influences and shared values (McNeil, Ronald D., 1995).

Different organizations often unite forces to achieve shared goals around capacity building and community enhancement. Numerous kinds of partnerships are sorted into Partnerships among community-based nonprofit service organization, Cross-sector partnerships (between nonprofits and the business, government, and/or academic sectors) and Partnerships between donor organizations and recipients (John Mennel et al., 2013). Public private partnerships (PPP's or P3's) as one of the Cross-sector partnerships may be the best eminent, at least in community development domains. PPP's are the result of a contractual relationship between public organizations (say a municipal government) and private corporations to provide a public good (Walzer, Norman \& Lori York, 1998).

Of the numerous top purposes to create community partnerships, some of them show up. The first may be abbreviated because of the African saying: "If you want to go fast, go alone; if you want to go far, go together." Useful partnerships control the particular potency of the partner as well as rub it strategically towards the situation from hand. It much more function, as well as it for a longer period, nevertheless strong partnerships construct the particular interrelationships, embraced comprehension, as well as group aims to engender ongoing development (John lavey, 2017). Second, you can find importance throughout employing a number of agencies, for two causes. Firstly, given that they performance ideal while many people definitely employ, community partnerships push agencies to discover as well as fully grasp concerns by several perspectives. Secondly, many of us learn very much while definitely paying attention, even when-especially- opinions and ideas face ours. Further than that, there may be additional chances to network, develop business, or maybe learn innovative methods that other people propose (Michael E. Porter et al., 2012).

Moreover, there are different types of relationship that can be founded among partners to ensure the accomplishment of shared goals; they are as follows (Tranel, Mark \& Kay Gasen, 2003):

- Collaboration includes huge independence and no enduring organizational responsibilities or merged services. Examples: imparting information; organizing efforts

- Strategic alliance implies common or assigned decision-making power. Examples: combined programming; administrative amalgamation

- Integration includes modifications to organizational configuration and control methods. Examples: joint ventures (two or more organizations establish a new structure to evolve a program-related function); mergers (previously discrete organizations joint program/administrative/governance functions)

- Funding alliance befalls when organizations combine to share a large grant/donation or build a beneficiary/donor relationship.

- Cost-sharing takes place when each organization offers different resources, such as facilities, staff, or equipment.

- Grant-match occurs when one organization offers a grant and the beneficiary provides counterpart services, cash, maintenance, supplies, or volunteers.

Barriers and pitfalls must be avoided throughout. Common barriers to successful partnerships include lack of clear purpose, missing key entities, hidden agendas, failures to communicate, and domination by one party. Successful partnerships avoid these and other failures to truly thrive. Community partnerships can be difficult to organize and sustain, but their ability to get things done cements their legacy as a vital facet of community building (Regina Brandstetter et al., 2006).

Hence, community partnerships can be as diverse and varied as the communities in which they're located and the issues they're formed to tackle. Some may be ad hoc committees, formed to quickly respond to a discrete community issue and can then be disbanded as quickly as they form (John lavey, 2007). Others form to take on larger projects, developing structures by which they operate and creating comprehensive strategies to advance their goals. But in a nutshell, a community partnership is a collaborative relationship between willing entities formed to address common objectives and create shared value (Timothy A.A. Stiles \& Trevor Davies, 2016). 


\section{A Framework to Create Shared Value Partnerships in the Community}

Nowadays, multinational Enterprises (MNEs) and small and medium-size enterprises

(SMEs) have more power than governments in determining where the future of our world goes (Ehrenfeld, 2009), yet, these companies are self-governed and often have never seen much of the land, air, or communities they impact. While Corporate Social Responsibility Statements (CSR) and philanthropic initiatives are growingly available in such companies, companies are also being held increasingly accountable to the damage being done to the earth (Porter et al., 2011). Whether this is right or wrong, business is the world's most influential citizen and no citizen can take on tasks such as climate change and environmental degradation alone.

Government taxes, grants and regulations can create opportunities for businesses - which possess a wealth of knowledge, ideas, capabilities and resources- and NGOs to change their way of working and doing business into one that creates shared value and benefits the community. So, building partnerships with business sector and NGOs will enable government to leverage each other's assets, connections, creativity and expertise to achieve mutually beneficial outcomes that satisfy its development objectives as well as business objectives (Andrew Crane et al., 2014).

The onset of globalization allowed companies to see themselves as global citizens without any single community to rely on, making them accountable only to themselves and government policy (Achbar et al., 2003). For this reason, governments have shifted from supporting industries to restricting them through taxes, quotas, monitoring systems, and transparency laws (Kunz et al., 2007). Many companies concede with legislation simply because they have to, not because it is in their best interest (Porter et al., 2011). In order for companies to act in the best interest of the communities where they work; it must be beneficial to the bottom line. Governments can be the initiator of such a shift by showing the value that can come through investing in society and the environment (L. Albareda et al., 2007).

Unfortunately, traditional Governments of many developing countries - as Egypt- look at spending as a cost, when citizens vote on taxes and policies they address them in terms of the added expense, but in fact each tax and policy set by government is aimed at adding value for society and therefore government is an essential entity in the relationship between society and business (S.R. Barley, 2007). The concept of shared value focuses on creating economic and societal value and minimizing costs; many governments focus on costs and regulation rather than value, but a shift towards promoting innovation and growth rather than limiting them is a key to a greener and prosper corporate world (J.P. Gond et al., 2011).

Then, government can become an agent of change through collaboration and creation of shared value across business firms, NGOs and individuals. Shared value is typically applied to companies but is equally applicable to governments (Porter et al., 2011). Thus, governments must strive to build strategic Partnerships with business companies and NGOs; to make platform investments and support shared value strategies. But when considering a potential partnership, some critical questions may arise: What benefits can a partnership provide? What organizations should we consider partnering with? How do we get a partnership process underway? The answer of such questions will lead us to build an effective creating shared value partnerships framework; its main stages are as follows (see figure 1):

\section{Stage 1: Context Analysis to define the mission/purpose to create shared value partnerships}

The aim of partnerships is to build far more values as compared with individual companies can do alone. Basically, the sum of a partnership is definitely above the particular sum of the person parts. Figuring out self-interest is definitely an essential part of this stage. Throughout denoting the need for a partnership, you need to assume not necessarily only about what are the partnership could accomplish as a whole, but with regards to the definite advantages to your business specifically (John lavey, 2007). Each potential partner - governmental agencies, Business Companies and NGOs- should analyze his surrounding context. The Context Analysis, therefore, takes stock of all the relevant societal trends, disruptive technologies, changing legislation, responsible business codes and standards, cross-sector partnerships and competitor activity (Visser \& Courtice, 2011). During this stage, the firms recognize what is the majority of critical mission; which often displays the pressures/priorities creating its working surroundings along with Focus on key shared value issues. This is certainly in line with the new ISO High level organization intended for maqnagement techniques, which often declares of which: "The firm will decide internal and external concerns that will be highly relevant to its aim along with that affect its ability to realize the planned outcome(s) of the management system." Therefore, Businesses pursue partnerships to include value as a result of bundled initiatives (Visser \& Kymal, 2015). 


\section{Stage 2: Leadership Review to identify the goals of shared value partnerships}

The context analysis should create a filter that distils the most material strategic issues for the business and its industry. Based on these insights, top management should review (and if necessary, revise) its values, vision and mission to ensure that they are truly aligned with the priorities identified in the first step. The material issues then need to be translated into strategic goals and targets. Companies can use established frameworks like the balanced scorecard (Kaplan and Norton, 1992); to capture these strategic sustainability goals (Figge et al., 2002; Möller \& Schaltegger, 2005), linking it to the growing practices around sustainability accounting and sustainability reporting (Schaltegger \& Wagner, 2006), or the goals can simply be integrated with existing strategic performance measurement systems in the company (Gates \& Germain, 2010). These goals will then act as another filter, leading to the identification of critical business processes that will enable the achievement of the strategic goals that create shared value in the community in which the company operates.

\section{Stage 3: Process Redesign and work plan development}

In this stage, business processes are mapped and redesigned in order to align with partners' value expectations, move towards the strategic goals, minimize risks and maximize breakthrough opportunities. For example, if eliminating corruption - as a shared value among partners- is a strategic goal, management will determine which business process is most critical; most likely procurement/purchasing (in the customer and supply chain process) and employee training (in the HR support process). By mapping out the process and determining key measures for that process, opportunities for improvement can be identified (Visser \& Kymal, 2015). Now, it truly is essential to establish a collaborative function plan in order to deal with the partnership's pursuits and direct the individuals' efforts. In which particular case partners were forced to acknowledge their overall performance management techniques; therefore employees know very well what they had to execute and just how it can be done (John Mennel et al., 2013). The finest action plan that reaps acceptance from people, are generally sensible, have quantifiable outcomes, as well as keep people accountable. Technological know-how could be a powerful learning resource to consolidate the application of collaborative work plans involving possible partners as well as support partnership standards and communication procedures (Spruill, Nina et al., 2001). There are a variety of programs that enable collaborating successfully with partners online. Four varieties of technologies mechanisms to use will be: options for disseminating information and facts, systems to get collaborating, systems to get real-time interface, along with systems to get handling the task.

\section{Stage 4: Systems Integration to execute the shared value partnerships}

This goal of integrating management systems for quality, environment, health and safety and social responsibility is well established in the literature (Almeida et al., 2014; Kymal et al., 2015; Mohamad F. et al., 2013). In practice, process owners must work with cross-functional teams to ensure that the organizational processes are capable of meeting the requirements defined by the various standards and strategic goals to create the intended shared value (Zhang et al., 2014). That is pursued by training to make certain the brand new and renewed procedures are generally fully understood, carried out and getting followed. Presently there is frequently vagueness or even discord in connection with allotment of accountability amongst the partnership and personal partners. As an illustration, it's difficult to clearly identify between strategic and operational (day-to-day) decision-making. Partners may be unwilling to delegate authority to the partnership. Hence, the partnership can generate a definitely published appropriate legal agreement or even long term contract (sometimes referred to as a "terms of reference"). This document sets out the key objectives, assets, procedures, structure, and outcomes of the partnership (Timothy A.A. Stiles \& Trevor Davies, 2016). It's also essential that this document reflect the business plan or strategy that forms the basis of the partnership's work. The document gives members an overview of how agreed-upon action will be taken and develops a sense of shared responsibility for the partnership's achievements and failures (A.G. Scherer and G. Palazzo, 2011). It also gives the partnership some structure and boundaries to work within, while allowing flexibility for creating shared value change and growth (Valerie Bockstette \& Mike Stamp, 2013).

\section{Stage 5: Monitoring the shared value partnerships}

It is crucial to monitor and report on the condition of the significant connection involving partners via formal process. This will help to recognize rumbling turmoil, unfavorable views, and also connection risks, which are able to be constructively attended to prior before partners undermine the partnership (Regina Brandstetter et al., 2006). It can be vital to behold through a number of relationships to recognize organizational boundaries to help effective partnering. 


\section{Stage 6: Evaluation and feedback of the shared value partnerships outcomes}

This stage includes the crucial steps of measuring the progress of the business on social objectives and the degree to which social performance improves economic value of the business. This process can take place by integrated reporting, auditing (internal and external) and management review, which creates the evaluation and feedback; which ensure continuous improvement loop that is essential for any successful management system (Bebbington et al., 2014). This means integrating the shared value creation process into the governance systems of partner organizations, including strategic planning and budgeting, management or business review, internal audits, and corrective actions (Eccles et al., 2014). This is what will ensure that implementation is happening and that the company stays on track to achieve its transformational goals; that yield the creation of shared value partnerships in the community. Moreover, to use insights to unlock additional shared value.

To conclude, such proposed strategic framework to create shared value partnerships in the community is an important evolution of the corporate responsibility and sustainability movement. It combines many of the ideas and practices already in circulation, but signals some important shifts, especially by using the language of integration, partnerships and value creation. These are generally principles that organization comprehends in addition to can also have thrilled about. It's a technique regarding turning a propagation involving societal desires in addition to stakeholder anticipation to a trustworthy business retort, without undercutting the stability of the business. On the other hand, this creating shared value partnerships framework aspires to become an instrument regarding combined innovation in addition to alteration; which is necessary for business to play a crucial role in solving our global problems, instead to be a part of these problems.

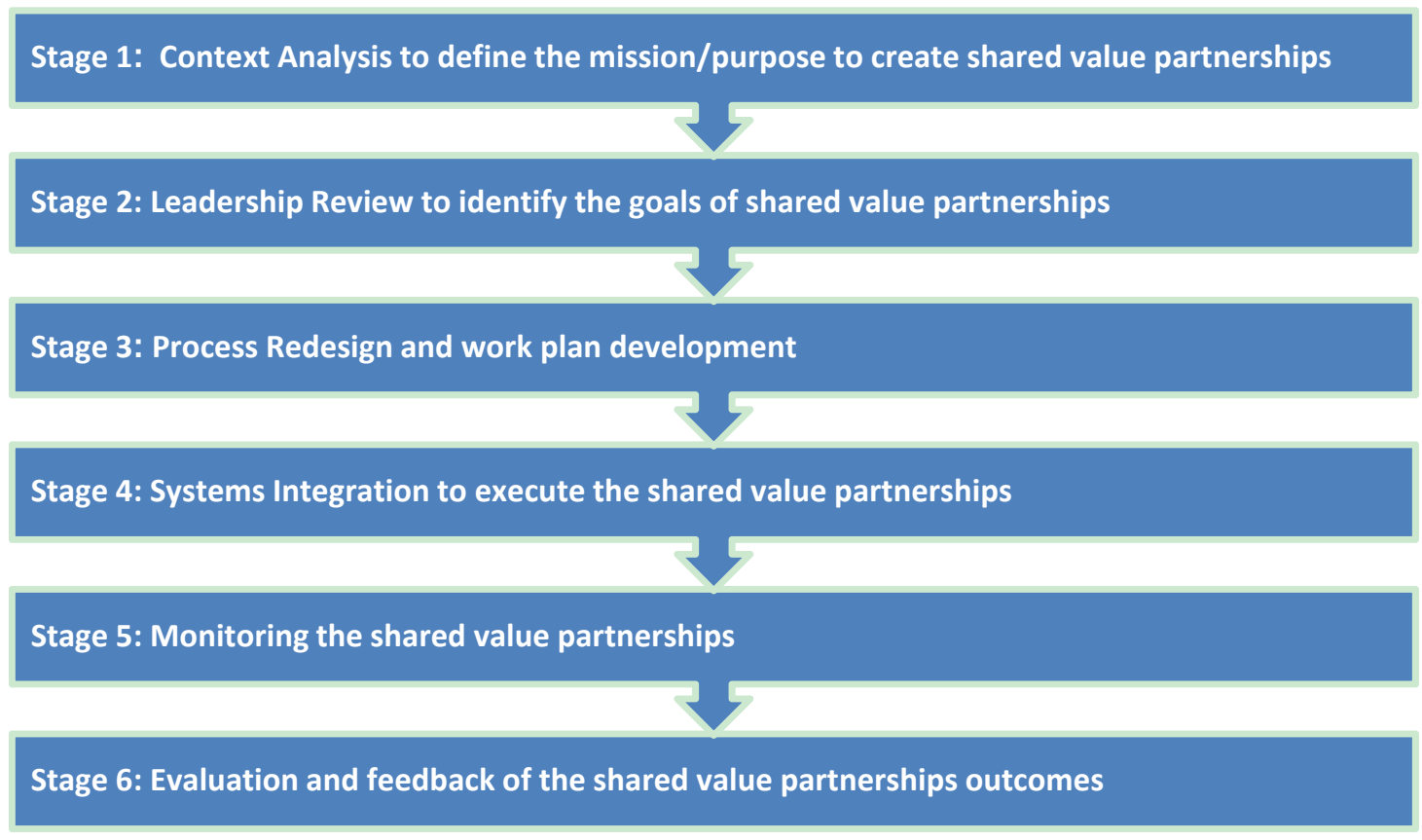

Figure 1. A framework to create shared value partnerships in the community

\section{Creating Shared Value Partnerships in Egypt: Barriers and Pillars of Effectiveness}

For many years, Egypt whines - as one of the developing countries - from many critical problems (economic, political, managerial, cultural, social, technological....) that impede its path to realize the intended sustainable development. Thereby, the Egyptian government must strive nowadays- energized by the people aspirations embodied at 2011 and 2013 uprisings- to formulize an applicable sustainable development strategy. Such intended strategy had to be implemented collectively -in the context of good governance insights and new public management principles- by all the stakeholders in the society.

Accordingly, one of the government priorities recently was to support the growing alignment between business and development; which is based on the recognition that the private sector will play an essential role in meeting the social and economic development challenges in our region. Therefore, the concept of shared value had to form the foundation of the Egyptian government vision - that businesses can deliver sustainable social impact in developing countries while achieving commercial returns. 
Then, Finding new and creative ways to increase collaboration and partnering between government, the private sector and NGOs will be critical to realizing this vision.

Hence, the aforementioned framework to create shared value partnerships is an essential necessity to ensure the persistence of shared value circulation among different stakeholders in the Egyptian community. Unfortunately, the Egyptian path towards the adoption of such suggested framework is crippled by many barriers; which apparently increase after 2011 uprising and its consequences. Thus, these barriers had to be illustrated and some pillars of effectiveness had to be suggested.

\subsection{Barriers to Effective Creating Shared Value Partnerships in Egypt}

There are many barriers for working effectively to create shared value partnerships in the Egyptian community. As relationships evolve, partners must work to overcome any path barriers that may take place. Governmental agencies, Business enterprises and NGOs in Egypt face various barriers; that impede their ability to apply the suggested framework to create shared value partnerships; due to its deficient internal environment and unstable surrounding external environment. Such barriers can be incarnated as follows:

\subsubsection{Administrative and Structural Barriers}

Many administrative and managerial barriers impede the Egyptian business enterprises attempt to effectively creating shared value partnerships in the community. Such barriers are as follows (Omran, 2013; Yassin, 1994; Timothy A.A. Stiles \& Trevor Davies, 2016; Mennel et al., 2013):

- Limited vision or failure to inspire and lack of clear purpose or inconsistent understanding of purpose as potential partners in the Egyptian community often do not share the same values and interests; which cause eventually the lack of commitment and unwilling participants; that hinder the creation of shared value partnerships.

- Lack of details in relation to the partnership structure (particularly the leadership position) and an unclear division of tasks, responsibilities, accountability, risks and benefits.

- The inequalities in partners' resources and expertise usually determine their relative influence in the partnership's decision making. Thus, one person or partner could have all the power and/or drives the process for his self- interest; in a way that can undermine such partnership.

- Differences in philosophies, work styles and culture among potential partners; who do not share the same values and interests. This can make agreements on the creation of shared values partnerships goals too difficult.

- The tendency of the business enterprises' structures in Egypt -especially at the public sector- to centralization, rigidity and closeness in a way that impedes its ability to collaborate, learn, share knowledge and create shared value partnerships with Key stakeholders; and adapt via an appropriate value stream all over the organization.

- Partnership members from organizations with decision-making power in the partnership do not have the suitable skills or training to identify issues or resolve internal conflicts. Moreover, Businesses leaders neglect to build an adequate organizational culture, rewards systems and incentives structures; necessary to motivate their employees to better managing create shared value partnerships.

- Deficiency of processes and procedures necessary to build and manage effective shared value partnerships operations (e.g. financial control, negotiation); Lack of adequate monitoring and evaluation systems to ensure continuous improvement loop; that is essential for any successful shared value creation process.

\subsubsection{Social and Cultural Barriers}

The culture of collaboration and partnership in the Egyptian community are almost fainted. Whereby, the majority of societal organizations - whether they are public or private- didn't encourage any attempt to partner with others - especially the government- as they didn't have confident in their true intentions. Always, they claim that others got a hidden agenda to harm their business (Crane et al., 20014). Therefore, each part in the community often plays individually - in a competitive way- an alleged social role to serve his own interests in the community; which hinder the likelihood to create effective shared value partnerships; in spite of its important role to realize the desired sustainable development in the Egyptian community (Egyptian Cabinet IDSC, 2011).

\subsubsection{Legal Barriers}

The lack of Legislations that advocate the good governance, transparency and the freedom of information exchange in Egypt; which are necessary to enhance the shared value partnerships (Omran, 2017). Furthermore, the law of business corporations and the law of local management in Egypt are not supportive enough to the notion of collaboration and participation among different societal organizations; necessary to create adequate 
shared value partnerships in the community.

\subsubsection{Funding Barriers}

It is not possible to talk about creating shared value partnerships in the community without looking at the wider funding environment. While Egyptian organizations suffer from lack of sufficient ongoing resources (e.g. knowledge, information, time, expertise, technology infrastructure and finance); financial resources are limited to a certain period of time, as compared with partnership funding linked to ongoing projects. Then, funding tied to particular projects or programs does not lend itself to create shared value initiatives outside the project box or facilitation of organization-wide or inter-organizational partnerships (Regina Brandstetter et al, 2006). Likewise, there needs to be recognition of the power dynamic of a funder, being in control of the key resources of a partner, and how this may impact on their willingness and openness to take risks, be innovative and share mistakes. This underlines the relational aspect to create shared value partnerships in the community (Crane et al., 2014).

\subsection{Adequate Pillars of Effectiveness to Create Shared Value Partnerships in Egypt}

The government and the business companies in Egypt - whether they are public or private- had to follow an adequate path of reforming; to overcome the aforementioned barriers and be able to create effective shared value partnerships in the community. Then, such firms will become an effective shared value partner; able to create, circulate and maintain adequate shared value partnerships to their success. Hence, the suggested reforming pillars - needed to apply the aforementioned framework of creating shared value partnerships in the communityare in the context of new public management principles and corporate good governance indices as transparency, collective participation, pervasive accountability and efficient management of economic resources; to overcome the barriers to effective creating shared value partnerships in the Egyptian community; can be as follows:

- Leadership commitment: Community partnerships are leader's collectives. Corporate leaders had to articulate a vision of the company as an engine for creating shared value partnerships in the community. Creating shared value starts with an explicit strategic decision by such corporate leaders. Whereby a commitment at the top management is a must, to make companies able to allocate the resources, focus, and create long-term thinking required to make a meaningful impact (John lavey, 2017). Moreover, engaged senior managers set the tone, and unleash the energy and creativity of the entire firm. The voice and credibility of the CEO, in particular, can be an important tool to leverage other interested parties, and bring new ones to the table to create shared value partnerships in the community (Tranel, Mark \& Kay Gasen, 2003).

- Developing an aligned Vision and articulating ambitious goals: Each partner must be pursuing the same essential goal. This does not mean they are committed to the same outcomes, approach, values systems and the like - in fact; disagreement about these can be healthy for the group. But it must be moving in the same general direction. Thus, in order to create shared value, the vision must be translated into a clear strategy that prioritizes shared value key issues and focuses on a limited set of relevant opportunities and articulates ambitious, measurable impact goals; that provide a basis for internal and external accountability (Valerie Bockstette \& Mike Stamp, 2013). Developing a strategy gives shape and direction to a company's engagement, ensuring that its efforts are mutually reinforcing and add up to meaningful change. A good strategy should be tailored to reflect a company's unique positioning, capabilities, and competitive landscape. It should identify a handful of genuine social challenges that also represent cost-reduction or growth opportunities, and prioritize the areas where it is best placed to act (Regina Brandstetter et al, 2006). Equally important, companies must shape this identification and prioritization process internally, rather than allow external stakeholders to be the driving force (Commonwealth of Australia, 2015). That way, they can retain control over their strategic agenda and maximize their chances of advancing strategic goals in ways that create value for society and the business.

Adequate lean organizational structure: For being efficient, a partnership should possess identifiable and also independent structure to aid determine its uniqueness. The structure should possess steadiness and also sustainability together with flexibility to evolve and adapt with any kind of shifting circumstances in the environment, and it is helpful in the event that it provides a certain amount of autonomy, i.e. independence from political impact (Timothy A.A. Stiles \& Trevor Davies, 2016). It is also important to review lines of communication to ensure that all partners are kept informed, involved and committed. This will help to delineate clear roles for participating members and their responsibilities in planning and implementation activities; and to alleviate confusion and streamlines the group's effectiveness (John lavey, 2017). Then, agreements are based on identifiable responsibilities, joint rights and obligations, and are signed by all relevant partners. Additionally, clear roles and responsibilities create channels of accountability. When partners understand how their contributions add value to the overall effort, and can see whether others are meeting their roles, it creates opportunities to improve their performances effectively (John Mennel et al., 2013). 
- Managing the shared value processes holistically across the organization with partners: In the most effective companies, social engagement is not confined to an isolated silo, but instead is integrated into a wide variety of roles and functions and often overseen at the board level. Rather than acting purely as grant administrators or report writers, CSR and philanthropy personnel play an orchestrating role, working to embed practices and coordinate multifunction projects throughout the company (Valerie Bockstette \& Mike Stamp, 2013). Most companies consult with stakeholders and work with NGOs, either as an implementing partner or a grantee. However, companies that create shared value partnerships go beyond this. They develop consultation processes that information, but do not allow the loudest voices to dominate the agenda. They also take part in coalitions that tap into a range of complementary capabilities from across fields and industries to tackle a common issue (OECD, 2016). Moreover, they Support activities to improve the processes of planning and co-operation to ensure the creation of effective shared value partnerships. Also, they had to set a precise and elaborated system of competences and duties of the managing bodies and deeper involvement of the strategic partners and legally defined relations among them (Smith, Steven R., 1997). In addition, companies had to put methodologies and working tools such as the Performance Management System and Total Quality Management process, using e.g. formal written memoranda of understanding among partners and tailored training programs; Mapping of socially marginalized localities and adoption of the appropriate measures. Finally, they had to create a well-established information and communication strategy; that ease the participation and collaboration among potential partners via various networks (Regina Brandstetter et al, 2006).

- Learning from measurement to improve efforts: Initiatives are structured for continuous learning and knowledge sharing practices among various partners to engender ongoing improvement — an essential step if ambitious impact goals are to be met. Companies had to measure their progress against impact goals and intermediate milestones; learn lessons from their activities and make adjustments; bring successful initiatives to scale, while discontinuing unsuccessful ones; and communicate in ways that engage and signal their peers, competitors, and markets (Valerie Bockstette \& Mike Stamp, 2013). The most successful initiatives are constantly on the lookout for opportunities to optimize investments and to rethink aspects that are not working as well as hoped. By crowdsourcing ideas, the company can move faster and address issues at scale. Opportunities to create shared value often lie in large, complex social challenges. To unlock solutions, it is essential to act at scale - otherwise, the impact on both social progress and corporate competitiveness will be negligible (Timothy A.A. Stiles \& Trevor Davies, 2016).

- Setting an appropriate Framework for Culture and Values: An understanding of cultural differences between partners and acknowledgement of those differences is critical; to enhance the creation of shared value partnerships tackling a bigger, longer term issue, developing a framework for how the group of partners can collectively work. Roles and responsibilities can always be comprised hereby; however the framework normally handles items like meeting guidelines, decision-making, behavior anticipations, turmoil and conflict resolve, and general goals and purpose (John Lavey, 2017). Then, Organizations had to embed the espoused values of collaboration and participation that advocate the culture of continuous improvement via the ongoing creation of shared value partnerships in the community. Then, the idea of mutual confidence and respect among the partners and a high level of information exchange necessary to create shared value partnerships in the community; must be aligned with the organization cultural beliefs and values; as a necessity to realize organizational economic benefits as well as social benefits to the community where it operates (Tranel, Mark \& Kay Gasen, 2003). Moreover, some reinforcing incentives had to be promoted to enhance the shared value notion adoption in the organization, and to boost the employees' commitment towards its practices.

- Communicating progress to both external and internal partners: Strong and consistent feedback loops grease the skids of understanding and progress. It's also one of the easiest things to achieve, especially today with the proliferation of smart phones and social media. Effective companies go far beyond traditional CSR reporting, employing a range of communications approaches to reach specific external partners groups in targeted ways (John Lavey, 2017). The organizations have a clear sense of who consumes the information they provide, what these people need to know, and how to meet those needs efficiently. Internal communication is particularly important. Employee engagement has long been at the root of corporate responsibility and social engagement practices. This is particularly true for companies that seek to create shared value (Regina Brandstetter et al, 2006). Shared value creation requires the active participation of a wide range of corporate functions. To develop a sense of shared ownership, employees must first understand and buy into the concept.

- Deploying a range of resources and assets to create the shared value partnerships: Having set ambitious goals for a handful of relevant issues, the most effective companies next mobilize a wide range of internal and external sufficient resources and assets to maintain and support the partnership (the necessary 
start-up funding). These assets can include cash, goods, services and technological infrastructures; the skills of employees; and political and business influence (Valerie Bockstette \& Mike Stamp, 2013). The most effective companies bring to bear an imaginative combination of assets in areas where they have an edge over other actors.

- Societal Awareness to the importance of shared value creation partnerships: Countless training programs and media campaigns in Egypt had to be planned and performed by the government; to notify publics, NGOs and various business companies about the important role of shared value partnerships; to create mutual benefits - economic and social benefits- respectively to the business companies and the surrounding community (Visser \& Kymal, 2015). Then, any potential resistance to create shared value partnerships can be evaded, and also to make members and institutions within the community aware about pertinent various trends to create adequate shared value partnerships among them.

- Initiating a political commitment and advocated legislations to enhance the creation of shared value partnerships: The political commitment of the Egyptian government to adopt the notion of strategic social partnership (SSP) between public sector, NGOs and private sector and to provide the needed infrastructure to realize so; is essential to create effective shared value partnerships in the community (John Mennel et al., 2013). Moreover, the legislations that advocate the integrity, transparency and the freedom of information exchange in Egypt; and which are necessary to enhance the creation of shared value partnerships; had to be issued as soon as possible (Wael Omran, 2017). Furthermore, the laws of local management, business corporations and investment in Egypt had to be modified to encourage -via various governmental economic incentives as tax and custom allowances, grants and regulations- the networking and collaboration among business firms and different societal organizations; to create adequate shared value partnerships in the community (Leah Armstrong, 2016).

\section{Conclusion}

From the earlier analysis, it is clearly that Government and NGOs cannot address the social challenges in isolation. Harnessing the power of business to drive prosperity and reduce poverty has never been more necessary or more possible than it is right now. Then, Creating Shared Value partnerships could be the solution, whereby this notion is mainly about creating economic value for businesses in a way that also creates value for the society by addressing its unmet needs. Businesses must work hard to reconnect companies' success with social progress and benefit.

It is also clear that when we talk about Shared Value it is not about sharing existing value (which is, essentially, what philanthropy is) but about creating new value for both shareholders and the community, together. Also, it is not corporate social responsibility in which companies focus primarily on building their reputation through activities that have limited connection to their business operations.

Accordingly, Shared value creates new opportunities for companies, civil society organizations, and governments to leverage the power of market-based competition in addressing social problems, and has grown rapidly from a global idea to a form of business practicing at its best. Then, the concept of shared value must form the foundation of developing countries vision; that businesses can deliver sustainable social impact in such countries as Egypt; while achieving commercial returns. Therefore, Finding new and creative ways to increase collaboration and partnering between government, the private sector and NGOs will be critical to realizing this vision. A successful partnership to create shared value enhances the impact and effectiveness of action through combined and more efficient use of resources; promotes innovation; and is distinguished by a strong commitment from each partner.

Hence, governments must strive to build strategic shared value Partnerships with business companies and NGOs; to make platform investments and support shared value strategies in the community. The strategic framework that leads to build such effective creating shared value partnerships in the community; may rely on the following stages: context Analysis to define the mission/purpose to create shared value partnerships, leadership Review to identify the goals of shared value partnerships, process Redesign and work plan development, Systems Integration to execute the shared value partnerships, monitoring the shared value partnerships and evaluation and feedback of the shared value partnerships outcomes.

Unfortunately, the societal organizations as Governmental agencies, Business enterprises and NGOs in Egypt face various barriers; that impede their ability to apply the suggested framework to create shared value partnerships in the community; due to its deficient internal environment and unstable surrounding external environment. Thereby, The government and the business firms in Egypt - whether they are public or private- had to overcome such barriers; by adopting some reforming pillars -in the context of corporate good governance principles and new public management indices- to enable the effective application of the aforementioned framework to create shared value partnerships in the community. 
To sum up, Shared value is a new approach recognizing the creation of both social and economic value as a competitive advantage; which can drive innovation and support the long-term adaptation and prosperity of the company. Then, the attention of the company is shifted from "shareholder" to "stakeholders." It is Broader in scope; stakeholders accommodate all the groups that would be directly affected by business operations including shareholders, customers, employees, partners and society. Hence, the suggested framework to create shared value partnerships in the community will be essential if business is to become part of the solution to our global challenges, rather than part of the problem.

\section{References}

Albareda, L., Lozano, J., \& Ysa, T. (2007). Public Policies on Corporate Social Responsibility: The Role of Governments in Europe. Journal of Business Ethics, 74(4), 391-407. https://doi.org/10.1007/s10551-007-9514-1

Almeida, J., Domingues, P., \& Sampaio, P. (2014), Different perspectives on management systems integration. Total Quality Management \& Business Excellence, 25(3-4). https://doi.org/10.1080/14783363.2013.867098

Armstrong, L. (2016). Reconciliation Action Plans - Creating Shared Value, paper was presented as a lecture in the Senate Occasional Lecture Series at Parliament House, Papers on Parliament no. 66, Canberra, on 22 July.

Barley, S. R. (2007). Corporations, Democracy, and the Public Good. Journal of Management Inquiry, 16(3), 201-215. https://doi.org/10.1177/1056492607305891

Bebbington, J., Unerman, J., \& O'Dwyer, B. (2014). Sustainability accounting and accountability. London: Routledge: 76-79.

Bockstette, V., \& Stamp, M. (2013). Creating Shared Value: A How-to Guide for the New Corporate (R)evolution, FSG: 1-28.

Brandstetter, R., Bruijn, H., Byrne, M., Deslauriers, H., Förschner, M., Orologa, A., \& Scoppetta, A. (2006). Successful partnerships a guide, Forum on Partnerships and Local Governance. OECD LEED at ZSI (Centre for Social Innovation), Vienna: 1-36.

Commonwealth of Australia. (2015). Creating shared value through partnership, ministerial statement on engaging the private sector in aid and development, August: 1-20. Retrieved October 20, 2015, from https://dfat.gov.au/.../creating-shared-value-through-partnership.pdf/

Crane, A., Palazzo, G., Spence, L. J., \& Matten, D. (2014). Contesting the Value of Creating Shared Value. University of California, Berkley, 56(2), 112-114. https://doi.org/10.1525/cmr.2014.56.2.130

Danielle Sponder Testa. (2011). the role of government in creating shared value between business, society, and the environment, MA Fashion and the Environment, Contextual Studies, Terms 1 and 2, March:1-17.

Eccles, R. G., Ioannou, I., \& Serafeim, G. (2014). The impact of corporate sustainability on organizational $\begin{array}{llll}\text { processes and } & \text { performance. }\end{array}$ https://doi.org/10.1287/mnsc.2014.1984

Ehrenfeld, J. (2009). Sustainability by design: A subversive strategy for transforming our consumer culture. New Haven and London: Yale University Press: 56-61.

Eichler, M. (2004). Consensus Organizing: Sharing Power to Gain Power. National Civic Review, 84(3), 256-262. https://doi.org/10.1002/ncr.4100840311

Farouk, M. (2014). Creating Shared Value: The Way Out? Can the new concept of Creating Shared Value replace traditional CSR and develop a country's economy? Retrieved October 14, 2018, from http://schools.aucegypt.edu/Business/ABR/Pages/Creating-Shared-Value-The-Way-Out.aspx

Figge, F., Hahn, T., Schaltegger, S., \& Wagner, M. (2002), the sustainability balanced scorecard -linking sustainability management to business strategy. Business Strategy and the Environment, 11(5), 269-284. https://doi.org/10.1002/bse.339

Gates, S., \& Germain, C. (2010), Integrating sustainability measures into strategic performance measurement systems: an empirical study. Management Accounting Quarterly, 11(3), 1-7.

Gond, J. P., Kang, N., \& Moon, J. (2011). The Government of Self-Regulation: On the Comparative Dynamics of Corporate Social Responsibility. Economy and Society, 40(4), 640-671. https://doi.org/10.1080/03085147.2011.607364 
Kaplan, R. S., \& Norton, D. P. (1992). The balanced scorecard: measures that drive performance. Harvard Business Review, January-February: 71-79.

Kramer, M. (2012). Introduction to shared value, Workshop on creating shared value through corporate social responsibility in India, November 8th.

Kramer, M. (2013). Shared Value: a new paradigm for corporate strategy. Retrieved October 18, 2018, from https://www.socialventures.com.au/sva-quarterly/shared-value-a-new-paradigm-for-corporate-strategy

Kunz, G., \& Garner, M. (2007). Going global: The textile and apparel industry. New York: Fairchild Publications: 33-36.

Kymal, C., Gruska, G., \& Reid, R. D. (2015). Integrated management systems. Milwaukee, WI.: ASQ Quality Press: 44-48.

Lavey, J. (2017). The value of partnership in community development. Retrieved September 8, 2018, from https://communitybuilders.org/what-we-think/blog/the-value-of-partnerships-in-community-development/

Mattei, S. (2015). What is the value of creating shared value? Department of Business and Management, Master thesis in Markets, Regulations and Laws, Libera universita intenationale degli studi sociali. Retrieved November 12, 2018, from https://tesi.luiss.it/14916/1/mattei-silvia-tesi-2015.pdf

McNeil, R. D. (1995). Partners in the Marketplace: A New Model for Business-Civic Leadership. National Civic Review, 84(3), 248-255. https://doi.org/10.1002/ncr.4100840310

Mennel, J., Mendelson, T., McElhaney, K. A., \& Marquard, B. (2013). The roadmap toward effective strategic social partnerships. Deloitte University Press: 1-24.

Mohamad, F., Abdullah, N. H., Mohammad, M., \& Kamaruddin, N. K. (2013). Management systems integration for organizational sustainability: quality, environmental, occupational health and safety, and energy. Applied $\begin{array}{llll}\text { Mechanics and } & \text { Materials, }\end{array}$ https://doi.org/10.4028/www.scientific.net/AMM.465-466.1155

Möller, A., \& Schaltegger, S. (2005). The sustainability balanced scorecard as a framework for eco efficiency analysis. Journal of Industrial Ecology, 9(4), 73-83. https://doi.org/10.1162/108819805775247927

Montgomery, D. B., \& Ramus, C. A. (2007). Including Corporate Social Responsibility, Environmental Sustainability, and Ethics in Calibrating MBA Job Preferences. Stanford Graduate School of Business, 101-104. https://doi.org/10.2139/ssrn.1077439

Moon, J., \& Vogel, D. (2008). Corporate Social Responsibility, Government, and Civil Society. In A. Crane, A. McWilliams, D. Matten, J. Moon, \& D. Siegel. (Eds.), the Oxford Handbook of CSR (pp. 303-323). Oxford: Oxford University Press. https://doi.org/10.1093/oxfordhb/9780199211593.003.0013

Moore, S. (2016). Shared value in banking: the community bank model case study. Retrieved November 26, 2018, from https://sharedvalue.org.au-2016.pdf/

OECD. (2016). Collaborative Strategies for In-Country Shared Value Creation: Framework for Extractive Projects. OECD Development Policy Tools, OECD Publishing, Paris. https://doi.org/10.1787/9789264257702-en

Omran, W. (2013). Bad Governance and Failure of Development Progress in Egypt: Causes, Consequences and Remedies. Journal of Public Administration and Governance, 3(4), 39-59. https://doi.org/10.5296/jpag.v3i4.4340

Omran, W. (2017). New emerging trends in organizational learning to business enterprises development with special focus on Egypt. Global Journal of Political Science and Administration, 5(5), 1-16.

Pfitzer, M., Bokcstette, V., \& Stamp, M. (2013, September). Innovating for Shared Value. Harvard Business Review, 88-96.

Porter, M. E. (2012). The Role of Business in Social and Economic Development: Creating Shared Value. World Bank CSV Discussion, Washington, D.C., August 2.

Porter, M. E., \& Kramer, M. R. (2011). Creating shared value, How to reinvent capitalism and unleash a wave of innovation and growth, from the January-February issue. Harvard business review.

Porter, M. E., Hills, G., Pfitzer, M., Patscheke, S., \& Hawkins, E. (2012). Measuring Shared Value: How to Unlock Value by Linking Social and Business Results, Workshop on creating shared value through corporate social responsibility in India, India's Public Sector, November 8th, 2012. 
Porter, M., \& Kramer, M. (2006). Strategy \& society: The link between competitive advantage and corporate social responsibility. Harvard Business Review. Retrieved April 5, 2017, from http://www.globalcompactnamibia.org/pdf/CSR\%20 - \%20Porter\%20Kramer\%20 - \%20CSR\%20along\%2 0the $\% 20$ value $\% 20$ chain.pdf

Roy, S. (2013). Corporate Shared Value: The New Competitive Advantage, by CCA LiveE on Friday, Jan 18th. Retrieved December 11, 2018, from https://www.triplepundit.com/2013/01/corporate-shared-value-new-competitive-advantage

Schaltegger, S., \& Wagner, M. (2006). Integrative management of sustainability performance, measurement and reporting. International Journal of Accounting, Auditing and Performance Evaluation, 3(1), 1-19. https://doi.org/10.1504/IJAAPE.2006.010098

Scherer, A. G., \& Palazzo, G. (2011). The New Political Role of Business in a Globalized World: A Review of a New Perspective on CSR and Its Implications for the Firm, Governance, and Democracy. Journal of Management Studies, 48(4), 899-931. https://doi.org/10.1111/j.1467-6486.2010.00950.x

Smith, S. R. (1997). Partnerships, Community Building, and Local Government. National Civic Review, 86(2), 167-174. https://doi.org/10.1002/ncr.4100860210

Spruill, N., Kenney, C., \& Kaplan, L. (2001). Community Development and Systems Thinking: Theory and Practice. National Civic Review, 90(1), 105-116. https://doi.org/10.1002/ncr.90110

Stiles, T. A. A., \& Davies, T. (2016). Unlocking the power of partnership, a framework to effective cross sector collaboration to advance the global goal for sustainable development. KPMG international cooperative, Swiss: $1-40$.

Tranel, M., \& Gasen, K. (2003). Community Partnerships: A Sustainable Resource for Nongovernmental Organizations. St. Louis, MO: UMSL Public Policy Research Center: 88-94.

Visser, W., \& Courtice, P. (2011). Sustainability leadership: linking theory and practice. SSRN, Working Paper Series, 21 October: $23-28$. https://doi.org/10.2139/ssrn.1947221

Visser, W., \& Kymal, C. (2015). Integrated Value Creation (IVC): Beyond Corporate Social Responsibility (CSR) and Creating Shared Value (CSV). Journal of International Business Ethics, 8(1), 1-14.

Walzer, N., \& York, L. (1998). Public-Private Partnerships in U.S. Cities. In N. Walzer \& B. D. Jacobs (Eds,). Public-Private Partnerships for Local Economic Development (pp. 61-67). Westport, CT: Praeger Publishers.

World Bank. (1998). Partnerships Group, Strategy and Resource Management, "Partnership for Development: Proposed Actions for the World Bank" (discussion paper, May 20): 5-6.

Yassin, E. (Ed.). (1994). Egyptian Bureaucracy, an Empirical Study. Cairo: Al Ahram Center for Political and Strategic Studies: 12-15.

Zhang, L., Cheng, J., \& Wang, D. (2014). The influence of informal governance mechanisms on knowledge integration within cross-functional project teams: a social capital perspective. Knowledge Management Research \& Practice, June: 121-129.

\section{Copyrights}

Copyright for this article is retained by the author(s), with first publication rights granted to the journal.

This is an open-access article distributed under the terms and conditions of the Creative Commons Attribution license (http://creativecommons.org/licenses/by/4.0/). 